\title{
PENGARUH SENAM ANTI HIPERTENSI LANSIA TERHADAP PENURUNAN TEKANAN DARAH LANSIA DI DESA KEMUNINGSARI LOR KECAMATAN PANTI KABUPATEN JEMBER
}

\author{
Misbakhul Anwari ${ }^{1}$, Rita Vidyawati ${ }^{2}$, Ropickhotus Salamah ${ }^{3}$, Mashila Refani ${ }^{4}$, Nur \\ Winingsih ${ }^{5}$, Dwi Yoga ${ }^{6}$, Rizka Inna ${ }^{7}$, Tantut Susanto ${ }^{8 *}$ \\ 1,2,3,4,5,6,7,8 Fakultas Keperawatan, Universitas Jember \\ Jl. Kalimantan No. 37 Kampus Tegal Boto Jember Telp./Fax. (0331) 323450 \\ *e-mail: tantut_s.psik@unej.ac.id
}

\begin{abstract}
ABSTRAK
Masalah kesehatan yang terjadi pada lansia umumnya adalah penurunan fungsi organ yang memicu terjadinya berbagai penyakit degeneratif termasuk hipertensi. Penyakit degeneratif pada lansia jika tidak ditangani dengan baik maka menurunkan kualitas hidup lansia. Hipertensi merupakan suatu gejala penyakit degeneratif kardiovaskuler yang paling banyak di alami oleh lansia dan belum dapat diketahui dengan pasti penyebabnya. Penatalaksanaan hipertensi pada lansia selain dengan farmakologi dapat pula dilakukan dengan non farmakologi seperti senam anti hipertensi. Penelitian ini bertujuan untuk mengetahui pengaruh senam anti hipertensi lansia terhadap penurunan tekanan darah lansia dengan hipertensi di Desa Kemuningsari Lor Kecamatan Panti Kabupaten Jember. Penelitian ini adalah penelitian kuantitatif dengan rancangan preexperiment design One Group Pre test-post test. Pengumpulan data menggunakan Sphygmomanometer air raksa, sedangkan analisis data menggunakan uji Wilcoxon Signed Rank Test. Hasil dari penelitian ini adalah tekanan darah sebelum pemberian intervensi sebagian besar adalah prehypertension $(87,5 \%)$, tekanan darah setelah pemberian intervensi senam hipertensi sebagian besar adalah normal $(87,5 \%)$, dan terdapat pengaruh senam anti hipertensi terhadap tekanan darah lansia di Desa Kemuningsari Lor Kecamatan Panti Kabupaten Jember (p-value = 0,001).
\end{abstract}

Kata Kunci : Lansia, senam hipertensi, tekanan darah

\section{PENDAHULUAN}

Meningkatnya penduduk lanjut usia dibutuhkan perhatian dari semua pihak dalam mengantisipasi berbagai permasalahan yang ada. Penuaan penduduk membawa berbagai implikasi baik dari aspek social, ekonomi, hukum, politik dan terutama kesehatan (Komnas Lansia 2010).

Meningkatnya populasi lansia ini tidak dapat dipisahkan dari masalah kesehatan yang terjadi pada lansia, menurunnya fungsi organ memicu terjadinya berbagai penyakit degeneratif (Azizah, 2011). Penyakit degeneratif pada lansia ini jika tidak ditangani dengan baik maka akan menambah beban finansial negara yang tidak sedikit dan akan menurunkan kualitas hidup lansia karena meningkatkan angka morbiditas bahkan dapat menyebabkan kematian (Depkes, 2013). Beberapa penyakit degeneratif yang paling banyak diderita oleh lansia antara lain, gangguan sendi, hipertensi, katarak, stroke, gangguan mental emosional, penyakit jantung dan diabetes melitus (Riskesdas, 2013).

Prevalensi hipertensi di dunia diperkirakan sebesar 1 milyar jiwa dan hampir 7,1 juta kematian setiap tahunnya akibat hipertensi, atau sekitar $13 \%$ dari total kematian (Gusmira, 2012). Prevalensi hipertensi di Indonesia untuk penduduk berumur diatas 25 tahun adalah 8,3\%, dengan prevalensi laki-laki sebesar $12,2 \%$ dan perempuan $15,5 \%$. Berdasarkan hasil Riset Kesehatan Dasar Depkes (Riskesdas) 2013, sekitar 76\% kasus hipertensi di 
masyarakat belum terdiagnosis. Hal ini terlihat dari hasil pengukuran tekanan darah pada usia 18 tahun ke atas ditemukan prevalensi hipertensi di Indonesia sebesar 31,7\% (Depkes RI, 2013). Hipertensi seringkali ditemukan pada lansia. Dari hasil studi tentang kondisi sosial ekonomi dan kesehatan lanjut usia yang dilaksanakan Komnas Lansia di 10 Provinsi tahun 2012, diketahui bahwa penyakit terbanyak yang diderita lansia adalah penyakit sendi $(52,3 \%)$ dan Hipertensi $(38,8 \%)$, penyakit tersebut merupakan penyebab utama disabilitas pada lansia (Kemenkes RI, 2013).

Olahraga seperti senam anti hipertensi mampu mendorong jantung bekerja secara optimal, dimana olahraga mampu meningkatkan kebutuhan energi oleh sel, jaringan dan organ tubuh, dimana akibatnya dapat meningkatkan aliran balik vena sehingga menyebabkan volume sekuncup yang akan langsung meningkatkan curah jantung sehingga menyebabkan tekanan darah arteri meningkat, setelah tekanan darah arteri meningkat akan terlebih dahulu, dampak dari fase ini mampu menurunkan aktivitas pernafasan dan otot rangka yang menyebabkan aktivitas saraf simpatis menurun, setelah itu akan menyebabkan kecepatan denyut jantung menurun, volume sekuncup menurun, vasodilatasi arteriol vena, karena menurunan ini mengakibatkan penurunan curah jantung dan penurunan resistensi perifer total, sehingga terjadinya penurunan tekanan darah (Sherwood, 2005).

Hubungan senam hipertensi terhadap pengendalian tekanan darah lansia sebagaimana disimpulkan dalam penelitian Wahyuni (2015). Penelitian menunjukkan terjadinya perbaikan tekanan darah pada lansia namun tidak mencapai taraf signifikansi yang diinginkan. Tidak tercapinya perbaikan tekanan darah yang diinginkan disebabkan adanya faktor perancu yang berhubungan dengan tekanan darah lansia antara lain pola makan, stress, aktivitas fisik, genetik serta farmakologi dalam penelitian yang tidak dapat dikendalikan.

Senam anti hipertensi merupakan olah raga yang salah satunya bertujuan untuk meningkatkan aliran darah dan pasokan oksigen kedalam otot-otot dan rangka yang aktif khususnya terhadap otot jantung. Mahardani (2010) mengatakan dengan senam atau berolah raga kebutuhan oksigen dalam sel akan meningkat untuk proses pembentukan energi, sehingga terjadi peningkatan denyut jantung, sehingga curah jantung dan isi sekuncup bertambah. Dengan demikian tekanan darah akan meningkat. Setelah berisitirahat pembuluh darah akan berdilatasi atau meregang, dan aliran darah akan turun sementara waktu, sekitar 30-120 menit kemudian akan kembali pada tekanan darah sebelum senam. Jika melakukan olahraga secara rutin dan terus menerus, maka penurunan tekanan darah akan berlangsung lebih lama dan pembuluh darah akan lebih elastis. Mekanisnme penurunan tekanan darah setelah berolah raga adalah karena olahraga dapat merilekskan pembuluh-pembuluh darah. Sehingga dengan melebarnya pembuluh darah tekanan darah akan turun.

Skrining tekanan darah telah dilakukan oleh mahasiswa program studi pendidikan profesi ners pada tanggal 26 Mei 2018 di RT 2 RW 6 Dusun Sumbersari Desa Kemuningsari Lor Kecamatan Panti Kabupaten Jember. Skrining dilakukan pada 17 lansia didapatkan hasil, yaitu 3 lansia dengan tekanan darah normal, 4 lansia prehipertensi, 6 lansia termasuak hipertesi ringan, dan 4 lansia termasuk hipertensi berat.

Upaya yang dilakukan mahasiswa program studi pendidikan profesi ners dalam menangani masalah ini adalah dengan senam anti hipertensi. Gerakan senam yang dilakukan adalah senam anti hipertensi secara umum perlu gerakan gerakan senam yang disesuaikan dengan 
kemampuan gerak lansia yaitu pada senam anti hipertensi.

Pencegahan penurunan fungsional tubuh pada lansia terutama tekanan darah tinggi dapat dilakukan dengan melakukan latihan fisik. Akan tetapi tidak semua latihan fisik sesuai dengan lansia mengingat kemampuan mobilisasi lansia terbatas. Oleh karena itu menggunakan senam anti hipertensi sebagai intervensi untuk menurunkan tekanan darah lansia hipertensi yang tinggal di RT 2 RW 6 Dusun Sumbersari Desa Kemuningsari Lor Kecamatan Panti Kabupaten Jember, sehingga peneliti tertarik untuk melakukan penelitian dengan judul, "Pengaruh Senam Anti Hipertensi Lansia Terhadap Penurunan Tekanan Darah Lansia Di Desa Kemuningsari Lor Kecamatan Panti Kabupaten Jember".

\section{METODE}

Penelitian ini adalah penelitian kuantitatif dengan rancangan pre experiment design One Group Pre testpost test dimana pada desain ini peneliti membandingkan nilai pre test yaitu sebelum dilakukan intevensi dan nilai post test yaitu setelah dilakukan intervensi. Populasi penelitian adalah seluruh lansia yang hadir di kegiatan tersebut. Senam anti hipertensi merupakan aktifitas fisik yang dilakukan berupa gerakan senam khusus penderita hipertensi yang dilakukan selama 4 menit.

\section{HASIL DAN PEMBAHASAN \\ Karakteristik Responden}

Tabel 1. Karakteristik responden

\begin{tabular}{|lcc}
\hline \multicolumn{1}{|c}{ Karakteristik } & $\mathrm{n}$ & $\%$ \\
\hline \multicolumn{1}{c}{ Jenis Kelamin } & & \\
\hline a. Laki - laki & 0 & $0 \%$ \\
b. Perempuan & 8 & $100 \%$ \\
\hline \multicolumn{2}{c}{ Umur } & \\
\hline a. $50-75$ & 7 & $87,5 \%$ \\
$\quad$ tahun & 1 & $12,5 \%$ \\
b. $>75$ tahun & & \\
\hline
\end{tabular}

\section{Tekanan Darah Lansia}

Tabel 2. Hasil pengumpulan data tekanan darah sistol dan diastol responden diperoleh tendensi statistik

\begin{tabular}{cllll}
\hline \multirow{2}{*}{$\begin{array}{c}\text { Nilai } \\
\text { Statistik }\end{array}$} & \multicolumn{2}{c}{ Pre tes } & \multicolumn{2}{c}{ Post tes } \\
\cline { 2 - 5 } & Sistole & $\begin{array}{c}\text { Diasto } \\
\text { le }\end{array}$ & $\begin{array}{c}\text { Sistol } \\
\text { e }\end{array}$ & $\begin{array}{c}\text { Diast } \\
\text { ole }\end{array}$ \\
\hline terendah & 130 & 60 & 110 & 60 \\
\hline tertinggi & 190 & 100 & 200 & 90 \\
\hline rata-rata & 151,43 & 85,36 & 140 & 82,10 \\
\hline median & 150 & 90 & 130 & 80,00 \\
\hline $\begin{array}{l}\text { Standar } \\
\text { Deviasi }\end{array}$ & 11,46 & 8,81 & 14,53 & 8,33 \\
\hline
\end{tabular}

Nilai tendensi statistik tekanan darah responden pada pre test diperoleh rata - rata sistole $151,43 \mathrm{mmHg}$ dan rata rata pre tes diastole $85,36 \mathrm{mmHg}$. Nilai rata - rata post test sistole $140 \mathrm{mmHg}$ dan rata - rata diastole $82,10 \mathrm{mmHg}$.

Tabel 3. Hasil Uji Wilcoxon Signed Rank Test

\begin{tabular}{|c|c|c|c|}
\hline \multirow{2}{*}{$\begin{array}{l}\text { Tekana } \\
\text { Darah }\end{array}$} & \multicolumn{2}{|c|}{$\mathrm{X} \pm \mathrm{SD}$} & \multirow{2}{*}{$\begin{array}{c}p- \\
\text { value }\end{array}$} \\
\hline & Pre & Post & \\
\hline \multirow[t]{2}{*}{ sistole } & 151,43 & $140 \pm$ & 0,001 \\
\hline & 11,46 & 14,53 & \\
\hline \multirow[t]{2}{*}{ diastole } & 85,36 & $82,10 \pm$ & 0,001 \\
\hline & 8,81 & 8,33 & \\
\hline
\end{tabular}

\section{Pengaruh Senam Hipertensi terhadap Penurunan Tekanan Darah Lansia} Berdasarkan hasil penelitian diketahui terdapat 8 responden yang mengalami penurunan tekanan darah setelah mengikuti senam antihipertensi. Dengan hasil uji statistik diperoleh nilai probabilitas 0,001 maka dapat disimpulkan bahwa senam lansia terbukti membantu menurunkan tekanan darah lebih cepat pada penderita hipertensi yang menjalani pengobatan farmakologis, dibandingkan penurunan tekanan darah pada penderita hipertensi yang hanya mendapatkan pengobatan secara farmakologis saja. Penelitian ini dilakukan dengan intensitas ringan, frekuensi latihan 1 kali seminggu 
dengan lama latihan 4-12 menit. Hasil penelitian ini sesuai dengan pendapat Rigaud yang menyatakan bahwa jenis olahraga yang efektif menurunkan tekanan darah adalah senam lansia dengan intensitas sedang. Frekuensi latihannya 3-5 kali seminggu dengan lama latihan 20-60 menit sekali latihan.

Nilai rata-rata tekanan darah sistol pre test $(151,463)$ lebih tinggi dibandingkan rata-rata tekanan darah sistol post test $(130,36)$ sehingga disimpulkan pemberian intervensi senam hipertensi berpengaruh terhadap penurunan tekanan darah sistol responden. Nilai rata-rata tekanan darah diastol pre test $(95,36)$ lebih tinggi dibandingkan rata-rata tekanan darah diastole post test $(82,14)$ sehingga disimpulkan pemberian intervensi senam hipertensi berpengaruh terhadap penurunan tekanan darah diastol responden.

Henuhilli menjelaskan bahwa senam lansia yang terdiri dari latihan pemanasan, latihan inti, dan latihan pendinginan yang mana gerakan-gerakan didalamnya bertujuan untuk menurunkan kecemasan, stres, dan menurunkan tingkat depresi. Penurunan tersebut akan menstimulasi kerja sistem syaraf perifer (autonom nervous system) terutama parasimpatis yang menyebabkan vasodilatasi penampang pembuluh darah akan mengakibatkan terjadinya penurunan tekanan darah baik sistolik maupun diastolik.

Penelitian yang dilakukan Titin tentang manfaat senam tera terhadap kebugaran lansia didapatkan hasil mampu menunjukkan bahwa senam dapat mempengaruhi tidak hanya stabilitas nadi, namun juga stabilitas tekanan darah, pernafasan dan kadar immunoglobulin, dengan hasil uji analisis statistik untuk kategori tekanan darah sistolik p-value 0.02 berarti $a<p=0,05)$ artinya terdapat perbedaan tekanan darah antara lansia pada kelompok perlakuan dan kontrol.

Menurut Tulak dan Umar (2017), hipertensi pada lansia terjadi akibat proses penuaan pada lansia yaitu terjadi kemunduran fisiologis yang menyebabkan kekuatan mesin pompa jantung berkurang serta arteri besar kehilangan kelenturannya dan menjadi kaku dan, tidak dapat mengembang pada saat jantung memompa darah melalui arteri tesebut yang mengakibatkan naiknya tekanan darah. Adanya pengaruh senam lansia terhadap penurunan tekanan darah lansia penderita hipertensi disebabkan oleh gerakan berupa senam lansia yang dilakukan oleh lansia merangsang peningkatan kekuatan pompa jantung serta merangsang vasodilatasi pembuluh darah sehingga aliran darah lancar dan terjadi penurunan tekanan darah. Hal tersebut sesuai dengan teori yang kemukakan oleh Maryam (2008) Pada usia lanjut kekuatan mesin pompa jantung berkurang. Berbagai pembuluh darah penting khusus di jantung dan di otak mengalami kekakuan. dengan latihan fisik atau senam dapat membantu kekuatan.

\section{KESIMPULAN}

Tekanan darah responden pada pre test diperoleh rata - rata sistole 151,43 $\mathrm{mmHg}$ dan rata - rata pre tes diastole $85,36 \mathrm{mmHg}$. Nilai rata - rata post test sistole $140 \mathrm{mmHg}$ dan rata - rata diastole $82,10 \mathrm{mmHg}$. Terdapat pengaruh senam hipertensi terhadap tekanan darah lansia di dusun Sumbersari Kemuningsari Lor Kecamatan Panti Jember.

\section{KEPUSTAKAAN}

Azizah. 2011. Keperawatan lanjut usia. Yogyakarta : Graha Ilmu.

Departemen Kesehatan Republik Indonesia. 2013. Profil Kesehatan Indonesia 2013. Departemen Kesehatan Republik Indonesia. Jakarta.

Gusmira, S. 2012. Evaluasi Penggunaan Antihipertensi Konvensional dan Kombinasi Konvensional Bahan Alam pada Pasien Hipertensi di Puskesmas Wilayah Depok. Makara. Kesehatan. Vol. 16: NO. 2. 77-83. 
Kemenkes RI. 2013. Buletin Jendela Data dan Informasi Kesehatan. Kemenkes RI. Jakarta.

Komnas Lansia. 2010. Profil Penduduk Lanjut Usia 2009. Jakarta.

Mahardani, N.M.A.F. 2010. Pengaruh Senam Jantung Sehat terhadap Penurunan Tekanan Darah pada Penderita Hipertensi di klub Jantung Sehat Klinik Kardiovaskuler Rumah Sakit Hospital Cinere tahun 2010.

Riset Kesehatan Dasar (Riskesdas). 2013. Kementrian Kesehatan RI, Badan Penelitian dan Pengembangan Kesehatan Kementrian Kesehatan RI. Jakarta.

Sherwood, L. 2005. Fisiologi kedokteran:dari Sel ke Sistem. Jakarta : EGC.

Tulak dan Umar. 2017. Pengaruh Senam Lansia Terhadap Penurunan Tekanan Darah Lansia Penderita Hipertensi di Puskesmas Wara Palopo.

Wahyuni, S. 2015. Pengaruh Senam Hipertensi Terhadap Tekanan Darah ansia di Posyandu Lansia Desa Krandegan Kabupaten Wonogiri. Skripsi: Program Studi S-1 Keperawatan Stikes Kusuma Husada Surakarta. Surakarta 